
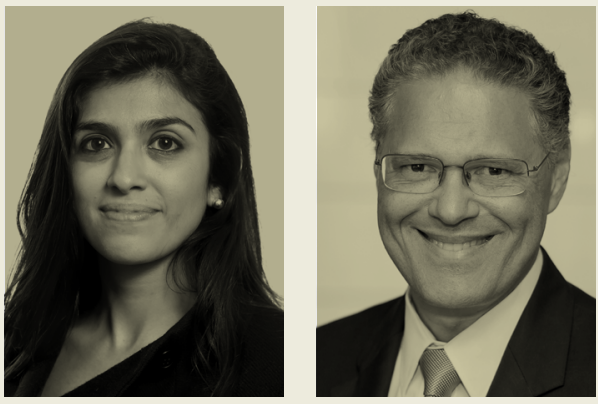

\title{
ENVELHECIMENTO NAS EMPRESAS
}

O envelhecimento da população é a mudança demográfica mais significativa no mundo neste início de século, com profundos impactos para a economia e a sociedade. No Brasil, esse fenômeno acontece de maneira muito rápida. $\mathrm{O}$ último relatório do censo demográfico, publicado pelo Instituto Brasileiro de Geografia e Estatística (IBGE) em 2010, revela que o alargamento do topo da pirâmide demográfica pode ser observado pelo crescimento da participação relativa da população de 65 anos ou mais. Os dados mostram que em 1991 esse grupo representava $4,8 \%$ da população, em 2000 , passou para $5,8 \%$ e em 2010 chegou a 7,4\%. A projeção é que esse número triplique em 2040. Além disso, a expectativa de vida alcançou o patamar de 75,6 anos de idade em 2016. Então, o brasileiro ganhou 30 anos a mais de vida desde 1940. Se o envelhecimento da população é inevitável, o mesmo acontece com a força de trabalho, gerando uma série de questões estratégicas para as organizações brasileiras.

Uma das reflexões pertinentes é o quanto as empresas estão preparadas para esse cenário. Uma pesquisa realizada com mais de 100 empresas - a maioria de grande porte -, pela Fundação Getulio Vargas (FGV) em parceria com a PricewaterhouseCoopers (PwC) em 2013, verificou que práticas específicas que colaboram para a melhor gestão do profissional maduro, ligadas ao processo de recrutamento e seleção, ao treinamento, ao desenvolvimento e à aposentadoria, por exemplo, eram pouco adotadas no âmbito organizacional. Para se ter uma ideia, políticas de remuneração ou benefícios diferenciados aos mais velhos e utilização de ergonomia apropriada à força de trabalho envelhecida no espaço de trabalho eram praticamente inexistentes no Brasil. E esse quadro mudou pouco desde então.
Isso acontece, muitas vezes, por conta do preconceito pela idade, que tem sido denominado globalmente de ageism. O que ocorre é que os profissionais mais velhos ainda são taxados como mais resistentes às novas tecnologias, menos produtivos e mais custosos. A experiência profissional e pessoal, no entanto, é pouco valorizada. A situação é paradoxal, na medida em que a sabedoria constitui um importante elemento em momentos de crise e grandes transformações.

Mantidas essas condições, é possível prever que as organizações enfrentarão um cenário em que não haverá mão de obra jovem suficiente no mercado e, ao mesmo tempo, existirá um grande contingente de profissionais experientes com pouca condição adequada de trabalho.

O ageism é preocupante, pois, além de prejudicar profissionais maduros dentro das organizações, por terem suas atitudes questionadas ou serem excluídos de determinadas atividades, também influencia aqueles que buscam uma oportunidade no mercado de trabalho. Nos últimos anos, o desemprego no grupo de pessoas com 60 anos tem aumentado, mas o interesse desses profissionais em continuar na ativa permanece. Algumas empresas têm oferecido determinadas vagas, como as de atendimento, para esse grupo de pessoas, mas não parece ser o suficiente.

A exemplo do que ocorre em países da Organização para a Cooperação e Desenvolvimento Econômico (OCDE), que possuem economias competitivas, mesmo com força de trabalho mais velha que a do Brasil, é necessário que nossas organizações revejam suas práticas de gestão para aproveitar o potencial dos profissionais maduros e manter patamares elevados de produtividade no futuro. 